\title{
Belphégor
}

\section{Lund, Martin. Re-Constructing the Man of Steel, Superman 1938-1941, Jewish American History, and the Invention of the Jewish-Comics Connection}

\section{Chris Reyns-Chikuma}

\section{(2) OpenEdition \\ Journals}

Electronic version

URL: http://journals.openedition.org/belphegor/947

DOI: $10.4000 /$ belphegor.947

ISSN: 1499-7185

Publisher

LPCM

\section{Electronic reference}

Chris Reyns-Chikuma, « Lund, Martin. Re-Constructing the Man of Steel, Superman 1938-1941, Jewish American History, and the Invention of the Jewish-Comics Connection », Belphégor [Online], 15-2 | 2017, Online since 02 November 2017, connection on 23 September 2020. URL : http:// journals.openedition.org/belphegor/947 ; DOI : https://doi.org/10.4000/belphegor.947

This text was automatically generated on 23 September 2020 .

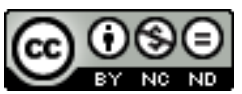

Belphégor est mis à disposition selon les termes de la Licence Creative Commons Attribution - Pas d'Utilisation Commerciale - Pas de Modification 4.0 International. 


\section{Lund, Martin. Re-Constructing the Man of Steel, Superman 1938-1941, Jewish American History, and the Invention of the Jewish-Comics Connection}

Chris Reyns-Chikuma

\section{REFERENCES}

Lund, Martin. Re-Constructing the Man of Steel, Superman 1938-1941, Jewish American History, and the Invention of the Jewish-Comics Connection, New York: Palgrave Macmillan (Contemporary Religion and Popular Culture), 2016, 215p. 


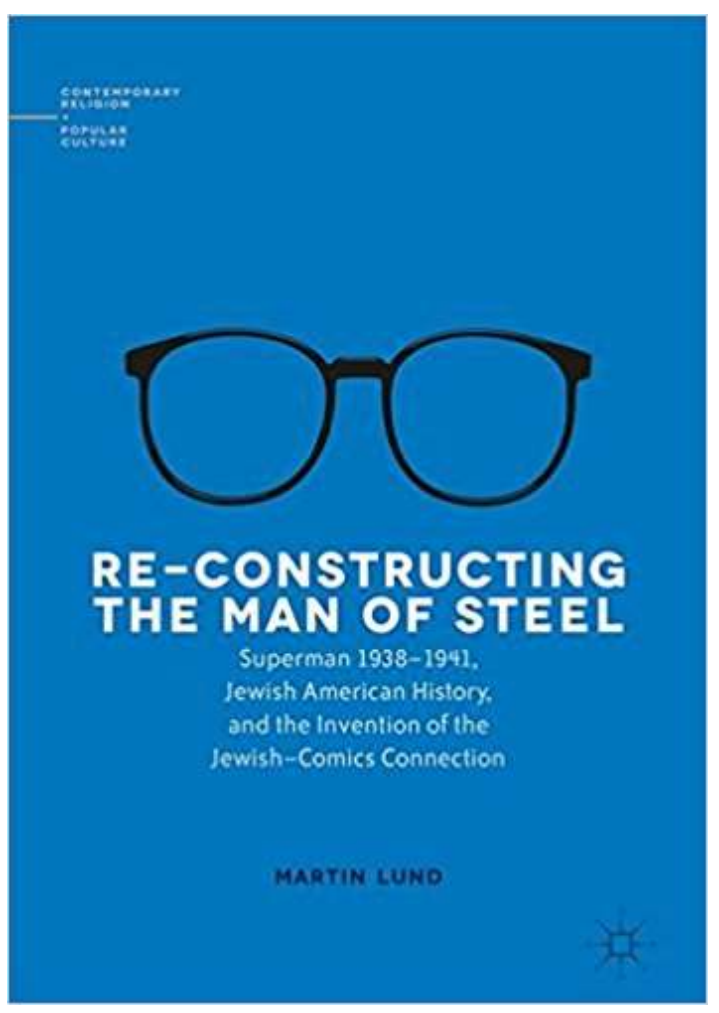

1 The basic purpose of this book is to de-construct the connection between Jewishness and comics. Since the late 1990s, many academic and newspaper articles, academic books, and even novels, have argued that Jewish culture had an essential and strong influence in the business and art of comics from the 1930s onward. Martin Lund, a postdoctoral student at Linnaeus University (Sweden), does not deny that there is a connection but also questions past evidence that has been too often circumstantial. He does this by re-placing these assumptions within their historical contexts. More precisely, he examines American identity formations alongside Jewish American and American history showing that this connection "emerges as an expression of what it meant for the discussed writers to be Jewish Americans in their own time" (back cover).

2 I must confess that when I started the book, I was quite skeptical. After all, there are so many books and articles, including many scholarly ones, which "prove" that there is a direct, obvious connection between Jewishness and comics! I read and taught with pleasure Chabon's book, which in spite of being just a novel, is an historical fiction based on a very good knowledge of Jewish history. And I often used the case of Superman and other superheroes as an interesting example of a symbolic reaction to Nazi Ubermensch.

3 However, after reading Lund's study, I have reasonable doubts, not on the connections themselves, but on the way the research on these connections was done until now. This is due to Lund's very good scholarship and an abundance of convincing arguments showing the weaknesses of most previous studies arguing for that connection. Obviously, he has read them all and has analyzed each one very thoroughly. He is also extremely well informed about various complex issues like identity formation, Jewish history, Jewish American history, and American and European contexts. This book is also a convincing example of how comics constitute a good site for historical research, because comics that sold millions of copies reflect the obvious modes of thinking 
during a certain period about, for example, issues like whiteness as a norm and the erasure of racial questions.

4 Lund examines every single sign that has been used to confirm or prove a Jewish connection with Superman, such as the name (Kal-el), the origin (Moses, Jewish immigrant fleeing from pogroms and Nazi Germany), the golem, in order to later deconstruct them. Nevertheless, this type of detailed micro-analysis is sometimes problematic (a word Lund often uses concerning other critics' arguments) in that it downplays those connections.

5 Let me give some concrete examples. A discussion about the meaning of Superman's name, Kal-el, could be interesting (p.71), but the point to me is not the correct meaning of the Jewish word but that the word, especially the way it is written, is recognizable by many readers as a sign of Jewishness, especially in the context of other signs. Similarly, when comparing Moses' and Clark's respective speech impediment, Lund presents it as unconvincing because "Moses' is permanent and Clark's is occasional" (p.74). However, I think that Clark's impediment itself (occasional or not) is enough as a reminder of Moses' impediment when added to the other signs. It is all of them together, including the parallel between the basket and the rocket, that hint at Moses, not one in isolation. Moreover, the fact that the reminders of this intertextuality are weak could be attributed to several factors. First, by not making them too obviously Jewish, it does not alienate the majority of white protestant readers; second, by not appearing just as an imitation of the Bible, it avoids what could be perceived as sacrilegious copies (as argued for example by Marco Arnaudo in The Myth of the Superhero, pp. 39-40). Lund also argues that this reference to Moses is too vague and that Superman's authors might have been inspired by "Sargon of Akkad's childhood basket-ride" (p.75). This vagueness might be true, but we are 100\% sure that the authors knew Moses' story; alternatively, there is no proof at all that they knew Akkad's story. Similarly, the fact that the Golem was used by others than Jewish people does not deny its importance in Jewish culture, especially for the Jewish immigrants coming from Eastern Europe, which is the case of many of the Jewish creators' families.

6 Furthermore, Lund argues that "[i]f Superman was an immigrant in any way but by default, he was one fully at home in his new country, neither undocumented nor there illegally having in both of Siegel and Shuster's comic book versions explicitly been turned over to an orphanage and consequently properly entered into the system" (p. 73). But it seems to me that it is difficult to defend the thesis that Siegel and Shuster were fully at home in the United States, even more if we consider that Shuster was actually an immigrant from Canada. Moreover, Lund writes: "[ $t]$ he most notable difference is that fictional Bund is de-Germanized by Siegel's giving their leader an Anglo-Saxon name" (p. 116). The fictional Bund is the group that resembles the muchdespised German-American Bund, which in the popular imagination was connected with the fifth column activities and Nazi Germany"(p. 116). So, Lund recognizes that Siegel is at the same time alluding to a real anti-Semitic Bund and a de-Germanized Bund. It seems to me that this de-Germanized version implies a compromise allowing not to refer to the real Bund and making anti-Semitism also Anglo-Saxon. Lund even goes on citing the anti-Semitic reaction of the Schwartze Korps about Superman (pp. 109-110), which reinforces the fact that Superman was perceived as Jewish by at least some people. 
7 It seems to me that if it is true that Superman is not the result of a frank Jewish commitment to enter the war, destroy Hitler and protect European Jews, it can be seen as a difficult compromise between some Jewish identity, some American feelings, some pro-peace convictions, and some commercial necessities. These necessities were for example not to oppose the boss, and with him the buyers who obviously were statistically not Jewish and, many even anti-Semitic. Other buyers were maybe just universalist, that is, mostly whites who wanted to ignore ethnic differences, just because recognizing them would downplay their own role as a universalist but still "white" model. (See p.117). The Superman text cannot be read unilaterally and simplistically either way, as pro-war or anti-war, but as a messy compromise: messy because the real and emotional stakes were high and the issues, complex.

8 By reminding us of the high number of lynchings during the 1930s-mainly of black people but also of Leo Frank, a Jewish man wrongfully accused of rape and murder (p. 151)-the case is made that Americans at that time were still capable of "radical and violent exclusion" similar to the violence against Jews by Nazis and Tsarist pogroms, and further confirms that for Jewish people, it was difficult to simply choose complete assimilation.

9 Showing that his predecessors made a lot of generalizations and, if not mistakes, at least approximations, does not mean that there was no connection between Jewish identity and comics. The statistics exist: there is a disproportionate number of Jewish creators in the comics world, especially in the superhero genre. Lund's explanation would be that one could not get a job in a different field because of discrimination, but this was valid also for other races and ethnic groups at that time (as acknowledged p.112). In addition, if we accept that it was only or mainly because of Jewish networking that these authors found jobs in comics, we still don't know why they created a Superman instead of Archie-type strips, just at the precise historical moment when Hitler was propagandizing the Ubermensch and discriminating against the Untermensch.

10 What this book shows very well is that "Jewishness," like identity in general, was a complex phenomenon and that we now need more dedicated scholars to use improved, more subtle arguments than the ones used before, in order to show that there was a connection between comics, more specifically the superhero genre and Jewishness.

11 Overall, I see two main problems with Lund's study: first, the absence of the concept of "thickness" or roundness (E.M. Forster) as a major characteristic of the superhero serial genre and second, the lack of the concept of negotiation.

12 One problem with Lund's analysis is the fact that he often takes only the very first publication as a source to refute other critics' Jewishness interpretations. What seems important to me is that when Siegel and Shuster wrote the story, first in 1934 and then in 1938-39, only a few hints were decodable as Jewish. Both still insecure teenagers, they had to eliminate or hide these clues, if only for commercial reasons and also most likely to show that they accepted assimilation and whiteness. However, Superman's story and those of similar heroes (Batman, etc.) are interesting because they accumulated "thickness" and "roundness," about Jewish issues, through their many episodes. As argued by Arnaudo, one of the main qualities in the Superhero genre is that it gains meaning through repetition and variation, and not through just one autonomous episode (p. 3-5). Therefore, it might be more interesting to take a bigger sample over a longer period (e.g. 1938-1945; 1934-1954). 
13 Lund is right to say that "for many American Jews, [...] the harshness and insecurities of the Depression, strengthened the resolve to pursue Americanization over alienation so as to become white" (151). However, this dynamic could have also inspired some Jewish people to keep what they perceived as their Jewish identity (even if only privately). Moreover, it is also reasonable to accept that what is hidden deep inside might re-surface in various ways and degrees in other cultural productions, especially the ones created so "impulsively" within a specific historical moment. It seems to me that it was more complex for many Jews and other minorities. They both compromised and negotiated in-between positions or alternative positions, in public and private, in their neighborhood and outside, in various forms and to various extents.

14 Lund's study is a very important one, first because it questions easy assumptions that were often too quickly made or repeated by journalists, teachers, and even scholars. Secondly, it is important because it re-contextualizes more precisely issues that have too often been ignored or have been applied to genres that are more "serious" or media like the novel, and maybe movies, but not comics. We now have one more high-quality piece of scholarship in comics, which can only be beneficial to the field and the researchers working in comics studies.

\section{BIBLIOGRAPHY}

Arnaudo, M. The Myth of the Superhero. 2013.

Forster, E.M. Aspects of the novel. 1927.

\section{AUTHOR}

\section{CHRIS REYNS-CHIKUMA}

Associate Professor at the University of Alberta (Canada) 